\title{
MIĘDZY ANTROPOLOGIĄ A LITERATURĄ. SCENARIUSZ KARNAWAŁOWY W POWIEŚCI WAŁERIJA SZEWCZUKA POMÓR
}

\author{
MARTA ZAMBRZYCKA \\ Uniwersytet Warszawski, Warszawa - Polska \\ МІЖ АНТРОПОЛОГІЕЮ І ЛІТЕРАТУРОЮ. \\ КАРНАВАЛЬНИЙ СЦЕНАРІЙ У РОМАНІ ВАЛЕРІЯ ШЕВЧУКА МОР \\ МАРТА ЗАМБЖИЦЬКА \\ Варшавський Університет, Варшава - Польща
}

АНОТАЦІЯ. Стаття являє собою аналіз карнавального сценарію в романі Валерія Шевчука Мор. Карнавальний сценарій визначається як аналогічний до сценарію обрядів переходу та пов'язаний з категорією sacrum. Автор спирається на теорію Роже Каійоса, який проаналізував структурні подібності між категорією sacrum та екстремальними ситуаціями „перебування на межі” (наприклад, під час війни).

\section{BETWEEN ANTHROPOLOGY AND LITERATURE. CARNIVAL'S SCENARIO IN VALERY SHEVCHUK'S NOVEL THE PEST}

\author{
MARTA ZAMBRZYCKA \\ Warsaw University, Warsaw- Poland
}

ABSTRACT. The subject of the article is an analysis of the carnival scenario in the novel The Pest by Valery Shevchuk. The carnival scenario is defined as a scheme analogical to the rites of passage and associated with the category of the sacred. It relies on the theory of Roger Caillois who analyzed the structural similarities between the sacred and the extreme experiences (like war).

$\mathrm{W}$

Tniniejszym artykule chcę przedstawić tekst literacki w kontekście badań kulturowych, odwołuję się więc do pojęcia ,antropologii literatury”. Tematem jest „wyczytanie” z powieści Wałerija Szewczuka Pomór ${ }^{1}$ (1989) karnawałowego scenariusza, rozumianego jako analogiczny do schematu obrzędów przejścia i ściśle związanego z kategorią sacrum. Będę się odwoływać do: opisanej przez Rogera Cailloisa koncepcji podobieństw w strukturze święta i doświadczeń granicznych - takich jak wojna oraz do koncepcji karnawału rozumianego jako scenariusz przejścia/zmiany. Uważam, że powieść Szewczuka odtwarza w języku lite-

\footnotetext{
${ }^{1}$ Utwór ten - nietłumaczony na język polski - został wydany w Ukrainie w roku 1989 we wspólnym tomie łączącym trzy utwory: Птахи з невидимого острова, Мор і Сповідь. Jest to jedna z części cyklu fillozoficznego, połączonego wspólną ideą duchowego odrodzenia bohatera.
} 
ratury uniwersalny, kulturowy scenariusz wykorzystując przy tym zestaw obrazów, kojarzonych z poetyką karnawału.

Ponieważ tematem jest opis scenariusza karnawałowego w utworze literackim, zawężam rozumienie terminu ,antropologia literatury” do koncepcji fikcjonalnych scenariuszy kulturowych i literackich Wolfganga Isera, pojmującego literaturę jako medium wskazujące na fikcjonalność wszelkich praktyk kulturowych ${ }^{2}$. Kategoria „scenariusza” wyodrębnia się w sposób najbardziej oczywisty w badaniach świąt, zabaw, widowisk, obrzędów oraz rytuałów. Jednym z nich - badanym zarówno w literaturoznawstwie jak i w antropologii kultury - jest karnawal ${ }^{3}$. Z wielu teorii i interpretacji można wypreparować stwierdzenie, że karnawał to przede wszystkim: święto, zabawa i widowisko, $i$ te jego aspekty powinny być badane łącznie ${ }^{4}$. Hasłami karnawalizacji w literaturze są: „świat na opak”, „odwrócenie hierarchii”, „zawieszenie praw i norm”, ,gra rolami społecznymi”, „przywdziewanie masek”. Są to - mówiąc ogólnie - aspekty kreowania czasowej antystruktury (w rozumieniu Victora Turnera).

W powieści Szewczuka można odnaleźć wiele z takich obrazów. Znajdujemy się w przestrzeni wymierającego miasta. Na jego ulicach panują jednocześnie zabawa i śmierć. Pojawiają się typowe dla bachtinowskiej karnawalizacji motywy „,́́wiata na opak”, opisy szaleńczej hulanki, zniesienia hierarchii społecznej i zawieszenia norm obyczajowych (w tym rozpasanie, nieumiarkowane obżarstwo i rozpusta). Pojawiają się też „karnawałowe przestrzenie” - przede wszystkim samo miasto $^{5}$, ulica i place targowe zaaranżowane w przestrzeń zabawy. Pozwolę sobie przytoczyć kilka cytatów:

Звідтіля неслися п’яні вигуки і вискотіла, аж захлиналася, музика. Там танцювали й пили чоловіки та жінки, обмінюючи все, що мали, на горілку6.

\footnotetext{
${ }^{2}$ Literatura umożliwia [...] coś, czego nie da się uzyskać w inny sposób: pozwala na czytanie kultury. Tym, co otwiera literaturę na czytanie kultury jest zdolność odkrywania jej własnej fikcjonalnej natury [...] literatura stanowi tym samym klucz do odszyfrowania procesów zachodzących w kulturze.

Cyt. za: W. I s e r, Czym jest antropologia literatury? Różnica między fikcjami wyjaśniajacymi a odkrywajacymi, [w]: „Teksty Drugie” 2006, nr 5, s. 24.

${ }^{3}$ Jak zauważa Rustam Kasimow w tekście Poetyka karnawatu i obrzędów przejścia: rozmyślania nad pojęciem ,karnawal”: „Po opublikowaniu prac Bachtina [...] pojęcie karnawału w utworach literackich stało się modnym i do pewnego stopnia wyczerpanym tematem współczesnej krytyki". R. K a s i m o w, Poetyka karnawatu i obrzędów przejścia: rozmyślania nad pojęciem „karnawal”, [w:] Karnawat. Studia historyczno-antropologiczne, wybór, opracowanie i wstęp W. Dudzik, Warszawa 2011, s. 281.

${ }^{4}$ Wydaje się, że w całościowym badaniu karnawału najbardziej przydatny byłby aparat pojęciowy, wywodzący się z teorii święta (Durkheim, Eliade, Caillios), teorii zabawy (Huizinga, Caillos, Schecher) i teorii widowisk (Schecher, Turner). Ale tylko łącznie. Karnawał jest bowiem zjawiskiem totalnym, wykraczającym poza granice każdej z nich.

W. D u d z i k, Karnawały - święta, zabawy, widowiska, [w:] „Konteksty. Polska Sztuka Ludowa” 2002, nr 3-4 (258-259), t. 59, s. 98-104.

${ }^{5} \mathrm{O}$ miejskiej naturze karnawału czytaj: M. C o z a r t R i g g i o, Czas poza czasem? Miejska dialektyka karnawału, [w:] Karnawat..., op. cit., s. 375-405.

${ }^{6}$ В. Ш е в ч у к, Мор, Львів 2004, с. 239.
} 
Lub:

Чоловіки обнялися за плечі й, [...] заспівали пісні. [...] Кілька п'яних [...] схопили жінок і товклися разом 3 ними в божевільному танку. По лицях усіх густо стікав піт, блищало мокре волосся [...] Якийсь чолов'яга волочив жінку, яка вискотіла і кусалася. [...] Майдан вирував. Крик і регіт, вискіт і плач, сварки і рик. [...] на брукові валялися п’яні чи хворі, дехто був закривавлений ${ }^{7}$.

Motyw zniesienia hierarchii społecznej znajduje wyraz zarówno w obrazach anektowania przez pijaną gawiedź przestrzeni opustoszałych pałaców jak również zrównania wszystkich w obliczu zarazy: „Що може зараз означати одежа? - понуро відказав странній. - Гляньте на отих: хто там шляхтич, а хто ремісник?”8, lub: „Ми бачимо смерть! [...] Але ми хочемо хоч раз пожити, як пани. [...] Ми теж хочемо побенкетувати в палаці, хочемо посидіти на золочених кріслах $[. . .]^{\prime 9}$.

W dalszej części analizy chcę się skoncentrować na innym aspekcie karnawałowego scenariusza - mianowicie na symbolach przejścia, ściśle związanych z kategorią sacrum. Zasadniczym tematem powieści nie jest bowiem świętowanie, tylko umieranie. Mimo, że opisana sytuacja nie jest zabawą (chociaż zawiera wiele jej elementów), można powiedzieć, że odzwierciedla najgłębszy sens karnawału, rozumianego jako okres symbolicznej śmierci starego i narodzin nowego świata (ładu, relacji). O symbolice śmierci i odrodzenia w karnawale pisali właściwie wszyscy jego teoretycy, od Bachtina po Eliadego. Bachtin określał karnawał jako „dramat równoczesnej śmierci starego i równoczesnych narodzin nowego świata"10 ". Mircea Eliade pisał o nim jako o dramacie, „wyczerpania starego czasu” i kreacji nowego porządku $^{11}$. Rustam Kasimow w tekście Poetyka karnawału i obrzędów przejścia podkreślał zaś analogie między tymi dwoma scenariuszami kulturowymi ${ }^{12}$.

Karnawał nie jest więc jedynie zabawa, ani okresowym zaprzeczeniem porządku, lecz istotnym etapem liturgicznego kalendarza. Jest nierozerwalnie związany z pojęciem sacrum i - jak pisze Agata Kłocińska w tekście Karnawał wobec sacrum: „wskazuje na jakiś inny świat, na rzeczywistość poza - czy ponadświatową"13. Nie można więc oddzielić karnawału od kontekstu sacrum. Ale co ma z tym wspólnego śmierć od zarazy morowej? Zwróćmy się do klasyków fenomenologicznej teorii sacrum.

\footnotetext{
${ }^{7}$ Tamże, s. 240.

${ }^{8}$ Tamże, s. 235.

${ }^{9}$ Tamże, s. 264.
}

${ }^{10}$ M. B a c h t i n, Twórczość Franciszka Rabelais'go a kultura ludowa średniowiecza i renesansu, thum. A. i A. Goreniowie, Kraków 1975, s. 621.

${ }^{11}$ M. E 1 i a d e, Mit wiecznego powrotu, thum. K. Kocjan, Warszawa 1998, s. 64-65.

${ }^{12}$ Według mnie, jako że karnawał należy do obrzędów przejścia, logicznie będzie założyć, że i karnawałowość stanowi część składową bardziej ogólnego pojęcia określanego przez nas mianem poetyki obrzędów przejścia" - R. K a s i m o w, op. cit., s. 287.

${ }^{13}$ A. K ł o c i ń s k a, Karnawat wobec sacrum. O ludyczności kultury wspótczesnej, [w:] „Kultura i Wartości” 2012, nr 3, s. 123. 
W tekście Sacrum i wojna Roger Caillois porównuje strukturę czasu wojny i czasu święta, podkreślając przy tym, że podobieństwa te występują tylko na poziomie struktury, gdyż pod względem sensu i treści wojna i święto są zjawiskami całkowicie różnymi ${ }^{14}$. Zamieńmy opisaną przez autora Żywiołu $i$ ładu wojnę pojęciem zarazy/pomoru. Podobnie jak czas wojny, również czas zarazy oznacza nieludzki chaos, dominację destrukcyjnych sił wzbudzających grozę, poczucie bezsilności, nabożny lęk i rodzaj fascynacji - czyli zgodnie z koncepcją Rudolfa Otto - zestaw odczuć, doświadczanych wobec sacrum. Oba zjawiska stanowią całkowite przekroczenie codziennej ludzkiej kondycji, oznaczają konfrontację z sytuacjami granicznymi i dopuszczają zachowania zakazane w życiu codziennym (podobnie jak podczas karnawału). Oba są rodzajem rzeczywistości nadrzędnej, granicznej sytuacji egzystencjalnej, w której człowiek poddaje się siłom od niego niezależnym. Jako niszczący chaos, stan wojny (i zarazy) ma wiele wspólnego ze strukturą karnawałowego odwrócenia porządku i kwestionowania wszelkich norm. Ważna jest też kategoria czasu. Doświadczenie graniczne - jak wojna czy zaraza - stanowi swego rodzaju ,wyrwę w czasie”, dzieje się poza czasem. Podobnie - zdaniem Victora Turnera - karnawał osadzony jest ,poza zwykłym czasem historycznym, a nawet poza czasem niezwykłych wydarzeń świeckich. [...] karnawał to miejsce poza miejscem, czas poza czasem" $"$.

W takim momencie poza czasem, gdy stary porządek już nie istnieje a nowy jeszcze nie powstał, rozgrywa się fabuła powieści Szewczuka. Linia fabularna podzielona jest na dwie historie, oparte na schemacie walki dobra ze złem, sił ciemności z siłami światła. W owładniętym morową śmiercią mieście łączą się losy czwórki bohaterów. Ich relacje można rozpisać na dwie pary opozycji, w każdej parze jeden z bohaterów uosabia siły życia, światła, moralności drugi natomiast reprezentuje ciemną stronę rzeczywistości. Opozycyjny charakter bohaterów odpowiada schematowi „zrytualizowanego konfliktu” - jak określa karnawał Milla Cozart Riggio ${ }^{16}$. Losy bohaterów korespondują z losami miasta. Pierwsza historia, której protagonistami są mnich Hryhorij i samozwańczy inkwizytor „Sinonosy” odzwierciedla dominację sił ciemności. Pozytywny bohater (mnich) zostaje zniewolony i skazany na śmierć przez samozwańczy sąd inkwizycyjny. Gdy kara śmierci zostaje ogłoszona, a wyrok ma być wykonany, w mieście wybucha epidemia. Ta cześć powieści odpowiada karnawałowemu scenariuszowi pogrążania się świata w chaosie.

W momencie, gdy miasto jest bez reszty owładnięte śmiercią i szaleństwem pojawia się w nim druga para bohaterów - uosabiający najszlachetniejsze idee poświę-

\footnotetext{
${ }^{14}$ R. C a i 11 o i s, Wojna i sacrum, [w:] Antropologia widowisk, pod red. L. Kolankiewicza, Warszawa 2008, s. 280-286.

${ }^{15}$ V. T u r n e r, Karnawal, rytuat i zabawa $w$ Rio de Janeiro, [w:] Karnawat..., op. cit., s. 291-315, s. 291. Warto jednak pamiętać, że karnawał to równocześnie trwały element kalendarza liturgicznego, nie jest więc jednoznacznie „pozaczasowy” lecz być może związany z innym niż świecki odliczaniem czasu.

${ }^{16}$ M. C o z a r t R i g g i o, Czas poza czasem? Miejska dialektyka karnawału, [w:] Karnawat..., op. cit., s. 376 .
} 
cenia, ofiary i miłości aptekarz Iwan Alembek oraz tajemniczy bohater określany jako „Obcy” (Странній). Również ta para bohaterów odpowiada podziałowi na światło i ciemność, życie i śmierć. Alembek porównany jest w powieści do Chrystusa, niosącego krzyż z bezinteresownej miłości do ludzi ${ }^{17}$. Dobrowolnie pozostaje w zakażonym mieście, aby ratować i leczyć jego mieszkańców. Obcy natomiast jest uosobieniem śmierci, istotą pozbawioną duszy, wspomnień i tożsamości, które utracił podczas wojny. Swoją tożsamość próbuje odnaleźć pochłaniając dusze ofiar zarazy. Ten fantastyczny motyw przejmowania cudzych osobowości i wspomnień podkreśla nie-ludzki status bohatera. Martwota miasta odpowiada w pełni duchowej martwocie Obcego: „Пустка в місті, - подумав він, - як і в мені”,18, lub: „І йому здалося, що це місто зараз так само, як він, без свого я" ${ }^{\prime 19}$. Niekiedy wydaje się on tożsamy z epidemią: „Странньому стало не по собі. Відчував ніби провину, немовби сам пустив на місто мор. Начебто він сам мучив і катував [...] людей і від його волі залежить - згубити це місто чи зберегти" 20 .

O ile pierwszego z „negatywnych” bohaterów - inkwizytora Sinonosego -można uznać za symbol całkowitej ciemności, w której pogrąża się opisany w powieści świat, o tyle postać Obcego związana jest $\mathrm{z}$ ideą poszukiwania duchowej odnowy, odtworzenia ładu i pokonania chaosu. Bohater - podobnie jak owładnięte zaraza miasto - znajduje się w momencie przełomu, jest pograżony w mroku, ale szuka nowego życia, dąży do odrodzenia. O momencie przełomu i potrzebie cyklicznej odnowy czytamy w następującym monologu wewnętrznym Obcego:

Може наше життя потребує свіжої крові. А може ми живемо на якомусь зламі. [...] свіжа кров уливається у витрухлий світ, щоб замістити стару. Вона оновить життя, але прийде час і постаріє і вона. Тоді знову світле стане чорним, а чорне світлим. Тоді важке стане легким а легке важким ${ }^{21}$.

Podobnym momentem mroku, po którym ma nastąpić nowe życie jest wpisany w rok liturgiczny czas karnawału. Jak pisze Agata Kłocińska:

Skoro karnawał przynależy do roku liturgicznego, to symbolizuje określony czas w historii zbawienia, moment po śmierci Chrystusa na krzyżu. Tak jak wtedy w środku dnia zapanowały ciemności i świat pogrążył się w chaosie, tak pogrąża się w nim co roku w okresie poprzedzającym post. Karnawał to czas potrzebny po to, by świat (zarówno makro - jak i mikrokosmos) mógł się odrodzić. Z jednej strony w naszej zwykłej rzeczywistości zostaje uobecniony moment śmierci i zmartwychwstania Chrystusa, z drugiej - pojedynczy człowiek pogrąża się w chaosie, by ostatecznie oczyścić się z grzechu ${ }^{22}$.

Ta korelacja makro i mikrokosmosu oraz idea wykreowania nowego życia z czasowego chaosu jest doskonale widoczna w powieści Szewczuka. Pochłaniając

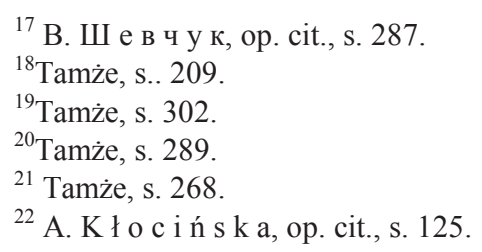


kolejne dusze, widmowy Obcy stopniowo odzyskuje zdolność do prawdziwego życia. Po przejęciu tożsamości ofiarnego i szlachetnego Alembeka, odradza się duchowo jako nowy, ,prawdziwy człowiek” (takim prawdziwym człowiekiem był Alembek), w duszy aptekarza odnajduje potrzebną do życia prawdę i mądrość:

Зазирнув Алембеку близько в очі і раптом пізнав те, в чому боявся признаватися собі досі - оті очі вже не належали бурмистру, але радше йому, странньому [...] Світло, яке побачив, зачарувало його і моровий странній збагнув, що він також зникає 3 цього світу і з міста. Входить у нове живе ${ }^{23}$.

Indywidualne odrodzenie bohatera znajduje swój odpowiednik w płaszczyźnie ponadindywidualnej - odradza się również zakażone miasto. Chaos epidemii zostaje pokonany za pomocą żywiołów ognia i wody. Dym z rozpalanych na ulicach, a następnie zalewanych wodą ognisk wygania $\mathrm{z}$ miasta roje much, które roznosily zarazę. Przestrzeń miasta odradza się więc dzięki podstawowym kosmicznym żywiołom, nabierając cech uniwersalnych. Można powiedzieć - w duchu Eliadego - że miasto jest odzwierciedleniem kosmosu, a jego odrodzenie oznacza ponowną kreację świata. Podobnie, opowieść o duchowym odrodzeniu bohatera ma cechy uniwersalnej przypowieści, opartej na inicjacyjnym schemacie symbolicznej śmierci i odrodzenia jako „prawdziwy, pełny” człowiek. Chaos epidemii - jak i chaos karnawału - nie prowadzi do zniszczenia, lecz do odtworzenia porządku codzienności. Jednocześnie jednak wskazuje na coś ponad tą codziennością. Agata Kłocińska twierdzi, że karnawał jednocześnie podważa i umacnia porządek kulturowy, wskazuje że „ludzki ład” nie jest ostateczny, a jednocześnie utwierdza w przekonaniu, że tylko w jego ramach możemy żyćc ${ }^{24}$. Uważam, że podobną funkcję pełnią wszystkie - ujęte w ramy kultury - doświadczenia graniczne. Ich znaczenie kryje się we wstrząsie jaki wywołują, otwierając czasowo perspektywę ponad codzienną, sakralną. Podobnie w powieści Szewczuka - odrodzony bohater nie jest tym samym człowiekiem, którym był przed utratą pamięci, odrodzone miasto nie będzie jedynie zwykłym miastem, lecz obrazem kosmicznego ładu, wyłonionego z konfliktu sprzecznych sił.

$\mathrm{Na}$ koniec chciałabym wrócić do związku między sacrum a sytuacjami granicznymi (takimi jak wojna, zaraza, śmierć, przemoc). Oczywiście, wskazanie relacji między sacrum a grozą i przemocą nie stanowi żadnego novum (wspomnijmy choćby Rene Girarda czy przywoływanego już Rogera Caillois'a). Przemoc, groza, lęk, śmierć (symboliczna) to komponenty wielu scenariuszy kulturowych, zarówno tych obrzędowo-rytualnych jak również należących do obszaru współczesnej kultury popularnej. Często mają one na celu wywołanie „oczyszczającego wstrząsu”, ustanowienie na nowo granic tego co normalne - nasze, i tego co obce, straszne, niepojęte. Sądzę, że podobne treści można odnaleźć w zaprezentowanej powieści Szewczuka. Jak większość scenariuszy śmierci i odrodzenia, również ta, literacka jego egzemplifikacja, posługuje się poetyką grozy i wstrząsu. Przede wszystkim

${ }^{23}$ В. Ш е в ч ук, op. cit., s. 316-317.

${ }^{24}$ A. Kł o c i ń s k a, op. cit., s. 125. 
autor opisuje wstrząsające, przerażające doświadczenie, ponad to wykorzystuje sugestywne obrazy degradacji moralnej i fizycznej, choroby, umierania i rozpadu. Jednocześnie wpisując fabułę $w$ uniwersalny kulturowy scenariusz przejścia wyraźnie określa relacje chaosu i ładu, niejako „przywraca porządek” i na nowo wyznacza granice ludzkiej rzeczywistości. Uważam, że ten właśnie kierunek badań - łączący problem literatury jako widowiska z problemami śmierci, lęku oraz przemocy stanowi niezwykle ciekawy kierunek dla antropologii literatury. Zakres tematyczny jest niezwykle szeroki - rozciaga się od scenariuszy rytualnych i obrzędowych przez literaturę piękną po fabuły kultury masowej (horror, kryminał, thriller). 